\title{
Agricultural trade reform and poverty reduction in developing countries
}

\author{
Kym Anderson
}

\author{
University of Adelaide, CEPR and \\ Development Research Group, World Bank \\ Washington DC 20433 USA \\ Phone +1 2024733387 \\ Fax +12025221159 \\ kanderson@worldbank.org
}

World Bank Policy Research Working Paper 3396, September 2004

The Policy Research Working Paper Series disseminates the findings of work in progress to encourage the exchange of ideas about development issues. An objective of the series is to get the findings out quickly, even if the presentations are less than fully polished. The papers carry the names of the authors and should be cited accordingly. The findings, interpretations, and conclusions expressed in this paper are entirely those of the authors. They do not necessarily represent the view of the World Bank, its Executive Directors, or the countries they represent. Policy Research Working Papers are available online at http://econ.worldbank.org.

Thanks are due to university seminar participants in Melbourne, Yale and Trinity College Dublin (TCD) for helpful comments and to the Asian Development Bank, the World Bank, IIIS at TCD and the University of Adelaide for financial support. Forthcoming in International Trade and Development: Essays in Honour of Peter Lloyd, edited by S. Jayasuriya and P.J. Lloyd, London: Edward Elgar, 2004. 


\begin{abstract}
This paper offers an economic assessment of the opportunities and challenges provided by the WTO's Doha Development Agenda, particularly through agricultural trade liberalization, for low-income countries seeking to trade their way out of poverty. After discussing links between poverty, economic growth and trade, it reports modeling results showing that farm product markets remain the most costly of all goods market distortions in world trade. It focuses on what such reform might mean for developing countries both without and with their involvement in the multilateral trade negotiations. What becomes clear is that if those countries want to maximize their benefits from the Doha round, they need also to free up their own domestic product and factor markets so their farmers are better able to take advantage of new market opportunities abroad. Other concerns of low-income countries about farm trade reform also are addressed: whether there would be losses associated with tariff preference erosion, whether food-importing countries would suffer from higher food prices in international markets, whether China's WTO accession will provide an example of trade reform aggravating poverty via cuts in prices received by Chinese farmers, and the impact on food security and poverty alleviation.
\end{abstract}

Keywords: WTO, agricultural protection, trade liberalization, poverty alleviation

JEL classification: F13, F15, F17, Q17 


\section{Agricultural trade reform and poverty reduction in developing countries}

Kym Anderson

The first of the eight Millennium Development Goals articulated at the UN General Assembly in 2000 was to halve by 2015 the proportion of people in absolute poverty, that is, those living on less than US\$1 per day and suffering from hunger. Throughout most of the $19^{\text {th }}$ and $20^{\text {th }}$ centuries, the number of people in the world that were poverty stricken had been increasing almost continually (Bouguignon and Morrisson 2002). Since the late 1970s, however, the number has declined by more than 200 million (Sala-i-Martin 2002). Remarkable though that recent achievement has been in such a short period, the World Bank estimates that there were still as many as one in five people, or 1.2 billion, below that poverty line in 2000 (e.g., Collier and Dollar 2002, Figure 3). ${ }^{1}$

Efforts to alleviate poverty for those remaining poor people, if they are to be successful, need to be based on a clear understanding of the reasons behind successful alleviation to date. The evidence presented by Sala-i-Martin suggests aggregate economic growth differences have been largely responsible for the differences in poverty alleviation across regions, a finding supported by numerous other studies (e.g., Dollar and Kraay 2002). Initiatives that boost economic growth are therefore likely to be helpful in the fight against absolute poverty.

Trade liberalization is such an initiative that tends to boost economic growth. ${ }^{2}$ But it also alters relative product prices, which in turn affect factor prices (Lloyd 2000; Ruffin and Jones 1977, 2004). Hence its net effects on poverty and hunger reduction depend also on the signs of those domestic product price changes and how

\footnotetext{
${ }^{1}$ Sala-i-Martin's data suggest the number has fallen to 350 million, at least in 1985 PPP terms. Even if that lower figure were to be correct, it is an unacceptable number of people in extreme poverty.

${ }^{2}$ The link between openness and economic growth, while not completely unambiguous and universal, is strong, and there is no evidence that openness is harmful to growth (see the discussion in McCulloch, Winters and Cirera 2001, Ch. 2). Trade's impact on growth can be much reduced in the absence of liberal domestic markets, macro stability, and appropriate institutions and infrastructure, however, since those are all necessary to enable producers to respond to changes in international market signals (Hoekman et al. 2001). For a comprehensive survey of the links between trade, growth and poverty, see Berg and Krueger (2002). The theory is also covered succinctly in Winters (2002) while a survey of the empirical evidence (at least for own-country liberalization) is available in Winters, McCulloch and McKay (2002).
} 
they affect domestic factor prices, on the price and quantity of food available for consumption, and hence on real individual and household incomes. If the price changes (whether due to own-country reforms and/or those of other countries) are pro-poor, then they will tend to reinforce any positive growth effects of trade reform on the poor, although the outcome depends also on the extent to which changes in border measures and complementary domestic policies do the following:

- Create new markets that are pro-poor;

- Stimulate the poor to respond to altered prices and new market opportunities;

- Provide second-round spillover effects that are pro-poor;

- Minimize any transitional unemployment that is concentrated on the poor;

- Raise government revenue that leads to pro-poor public expenditure; and

- Reduce the vulnerability of the poor.

The present paper explores the potential poverty implications of one aspect of the current Doha Development Agenda of the World Trade Organization (WTO) trade liberalization agenda. At the WTO Ministerial in Doha in November 2001, members agreed, in launching the next comprehensive round of multilateral trade negotiations (MTNs), that there would be a substantial focus on development concerns (see the Doha Ministerial Declaration in WTO (2001b)). Even so, numerous people in developing countries remain skeptical that they will receive sufficient gains from that MTN to warrant the inevitable costs of negotiations and adjustments. ${ }^{3}$ They (and some in the donor community) are skeptical not least because they perceive the OECD countries as unwilling to provide developing countries access to highly protected agricultural and textile markets. Some of them also are yet to be convinced that reducing distortions in world food markets would alleviate rather than add to poverty and food insecurity in developing countries. For example, those in net foodimporting developing countries worry that, because of a higher food import bill, their economies will be worse off because of agricultural trade reform that raises international food prices. Yet two-thirds of the world's poor live in rural areas and, in least-developed countries, the proportion is as high as 90 percent (OECD 2003, p. 3). If those poor rural households are net sellers of food, an alternative prior is that agricultural trade liberalization abroad would favor most poor households in countries

\footnotetext{
${ }^{3}$ Their scepticism is supported by recent reviews of the benefits to date to developing countries from the Uruguay Round. On the UR Agreement on Agriculture, for example, see Matthews (2002).
} 
where the boost to international food prices is transmitted to those food-surplus households. The issue becomes more complex for developing countries that also reduce their own distortionary trade policies, the poverty outcome of which depends heavily on whether that own-country reform raises or lowers the relative price of food domestically. Given these differing priors, the aspect of the WTO negotiations focused on in this paper is the poverty impact of agricultural policy reform relative to liberalizing trade in other goods. ${ }^{4}$

The paper addresses the effects of trade reform on global poverty at three levels: first on developing countries as a group; then on different types of developing countries; and finally on different types of households within developing countries. We begin by summarizing global economic modeling results showing the effects of goods trade distortions expected to still be in place in 2005 (that is, post-Uruguay Round). Those results support the view that agricultural trade policies remain by far the most costly of all goods market distortions in world trade. What also becomes clear from those results is that if developing countries want to maximize their benefits from the Doha MTN round, they need also to free up their own agricultural (and other) markets so their producers are better able to take advantage of new marketopening opportunities abroad. The paper then addresses such questions as whether some developing countries would be made worse off through tariff preference erosion, whether net food-importing developing economies would suffer from higher food prices in international markets, and whether Doha would worsen food security for the urban poor in developing countries. To help answer those questions by way of example, the paper also examines China's accession to WTO, which involves altering relative prices in China to a much larger extent than the Doha Round is likely to impose on WTO member countries. While the conventional wisdom has been that WTO accession for China will exacerbate poverty in that country, the results summarized below offer a somewhat more optimistic view, particularly if mooted reforms to domestic policies are implemented. The paper concludes with suggestions of ways to increase the prospects of a pro-poor reform outcome from the Doha

\footnotetext{
4 An additional reason for focusing on agriculture is that - contrary to conventional wisdom productivity growth in agriculture historically has outpaced that in manufacturing, including in developing countries (Martin and Mitra 2001). That empirical evidence suggests liberalizing markets for farm products could provide an above-average boost to economic growth in poor countries, ceteris paribus, which would add further to poverty alleviation. In so far as new agricultural technologies tend to have a labour-saving bias, however, maximizing the benefits from agricultural productivity growth requires flexible labour markets so that displaced farm workers can find employment readily in nonfarm sectors.
} 
Round, including changes needed to the domestic and trade policies of developing countries themselves to enhance their food security.

\section{Estimating national and global welfare gains from WTO trade reform}

\section{Which sectors and regions offer the largest potential global gains?}

What is the potential for welfare gains from the WTO's Doha Development Agenda? This question was addressed in an empirical study (Anderson et al. 2001), using an applied general equilibrium model of the global economy known as GTAP. ${ }^{5}$ According to that study, of all the economic gains to be had in 2005 from removing the barriers to trade in goods that will still be in place after all Uruguay Round commitments are implemented, almost half (48 percent) would come from agricultural and processed food policy reform in OECD countries (Table 1) - even though such products in those countries contribute only 4 percent of global GDP. But notice also that another one-sixth of the welfare gains would come from reform of farm and food policies of developing countries.

Textiles and clothing reforms would be the next largest contributor, although they appear small by comparison with agricultural reform: their potential global welfare contribution is only one-ninth that of agriculture's (7 percent compared with 65 percent). This big difference reflects two facts. One is that projected distortions to prices for agriculture are more than twice those for textiles and clothing in 2005 . The other is that textiles and clothing contribute only 1.5 percent to the value of world production and 5 percent to the value of world trade, half or less compared with the shares for farm products. ${ }^{6}$

\footnotetext{
${ }^{5}$ The GTAP (Global Trade Analysis Project) model is based in Purdue University (see Hertel 1997). It is a standard, multi-region model based on neoclassical assumptions of perfect competition, constant returns to scale and full employment. Currently it is in use by several hundred researchers in scores of countries on five continents. The data base builds on contributions from many of these individuals, as well as the national and international agencies in the GTAP Consortium.

${ }^{6}$ Two assumptions are crucial in generating the results reported in Table 1, however. One is that China and Taiwan, having joined the WTO at the end of 2001/start of 2002, enjoy the same accelerated access to OECD markets under the Uruguay Round Agreement on Textiles and Clothing (ATC) as other developing countries that were already WTO members. The other crucial assumption is that OECD countries fully implement the spirit of the ATC by the end of 2004, that is, they remove remaining import quotas and do not replace them with similarly protective instruments such as safeguard measures. Dropping either of those assumptions reduces very substantially the estimated gains from Uruguay Round implementation (Anderson et al. 1997), and therefore would raise the potential gains from textile and clothing reform in the next and subsequent WTO rounds above that reflected in Table 1.
} 
Which sectors offer the largest potential gains to developing countries as a group?

The distribution of the gains across regions that would result from full trade liberalization is clear from the upper half of Table 1. As always, most of the gains accrue to the liberalizing region. For example, all but one-tenth $(11.6 / 122.1)$ of the gains from high-income countries removing distortions to their trade in farm and food products accrues to those countries. Even so, that farm trade reform contributes more than one-quarter of the total welfare gains to developing countries from developed countries liberalizing their merchandise trade (11.6/43.1). As for developing countries liberalizing their own farm and food policies, three-quarters of the benefits therefrom stay with the developing countries themselves (31.4/42.6), and those policies contribute almost half of the gains from those countries' overall merchandise trade reform (31.4/65.1). In total, 26 percent $(43.0 / 164.7)$ of the gains from global agricultural trade liberalization would accrue to developing countries. ${ }^{7}$

Clearly, developing countries as a group have a major stake in the process of farm policy reform continuing: according to the model results in Table 1, farm and food policies globally contribute 40 percent (43.0/108.1) of the cost to developing economies of global goods trade distortions. Textile and clothing policies also harm them greatly, but barely one-third as much as farm policies. ${ }^{8}$ Table 1 shows that 57 percent $(25.6 / 45.1)$ of the potential welfare contribution to developing countries from global merchandise trade liberalization - and 74 percent $(12.3 / 16.7)$ of that from just farm trade liberalization -- would come from reforms by developing countries themselves. This reflects the importance not only of own-country reform but also of expanding South-South trade: between the 1980s and 2001, the share of developing countries' agricultural exports going to other developing countries rose from 28 percent to 37 percent (World Bank 2003, Table 3.6).

\section{What would be the impact of trade reform on international food prices?}

The above GTAP modeling study found that full liberalization of OECD farm policies would boost the volume of global agricultural trade by more than 50 percent,

\footnotetext{
${ }^{7}$ This compares with an estimate for 2015 of 32 percent in a study that examined just agricultural trade reform alone (Beghin, Roland-Holst and Mennsbrugghe 2003).

${ }^{8}$ It should be recognised that these results ignore the effect of tariff preference erosion. In so far as a developing country receives such preferences at present in OECD markets, the above results overstate the potential gains from their reforms. This point is taken up below.
} 
but would cause real international food prices to rise by only 5 percent on average. ${ }^{9}$ For the subset of low-income countries that would remain net food-importing economies after such a reform and thereby suffer a deterioration in terms of trade, the extent of the rise in their food import prices from a phased and partial reform (as distinct from the instantaneous and complete reform modeled above) would be indiscernible from other changes in terms of trade due to such things as exchange rate movements. Even the complete reform generates estimated losses for only two of the food-importing countries/country groups shown in the disaggregated Table 2, namely China and Middle East/North Africa. ${ }^{10}$

\section{Would rich countries gain more than developing countries from trade reform?}

The final two columns of Table 2 reveal that, even though developing countries would gain slightly less than rich countries in aggregate dollar terms from a move to global free trade in merchandise, they gain much more as a percentage of GDP: 1.9 percent, which is more than three times the percentage for rich countries. For Sub-Saharan Africa (other than South Africa) the gain would be 1.4 percent of GDP.

Furthermore, those developing countries would gain less if they abstained from reforming their own policies. To illustrate the point, the effects on low-income countries in Sub-Saharan Africa and South Asia have been examined first without and then with those economies participating in reform (Anderson and Yao 2003b). If all regions other than South Asia and Sub-Saharan Africa were to remove their trade distortions remaining after the end of 2004 when all Uruguay Round commitments are to have been implemented, the world economy would structurally adjust to allow each region to exploit even more its comparative advantages. Sub-Saharan Africa and South Asia would have to undertake some structural changes within and between key sectors even if they chose not to join in such a trade reform (Table 3(a)). In particular, agriculture would expand at the expense of labor-intensive manufacturing in those low-income countries. However, Sub-Saharan Africa would expand its agricultural

\footnotetext{
${ }^{9}$ Beghin et al. (2003) estimate a slightly higher price rise for numerous agricultural commodities (but close to zero for others), but their study does not include reform to non-farm trade and so overstates what the relative price change would be in a multi-sector agreement.

${ }^{10}$ This result from sector-wide multilateral reform is to be contrasted with that from reform of trade taxes on a single primary commodity that is grown by a few developing countries and whose demand is price-inelastic. In the latter case it is conceivable that the optimal export tax for those few countries is greater than zero if they were to cartelize, in which case reform could harm their economies while benefiting consumers globally. See, for example, the empirical study of West African cocoa by Gilbert and Varangis (2003).
} 
output more, and contract its manufacturing more, if it also undertakes reforms itself than if it stands aside from reform. The trade balance for the different product groups is affected by the above production effects plus changes in consumption, following relative price and income changes. By comparing Tables 3(a) and 3(b) it is evident that net food imports are less for Sub-Saharan Africa and South Asia following the removal of remaining trade barriers in 2005 , but more so when those developing countries participate in the reform.

\section{Would poor African countries gain more from Doha if they abstained from reform?}

The results in Anderson and Yao (2003b) suggest Sub-Saharan Africa's aggregate economic welfare gain is twice as great from participating in than from standing aside from further trade liberalization. However, most of that greater gain goes to the South African Customs Union. The reason that Other Sub-Saharan Africa as an aggregate does not gain more is that the very considerable gains from more efficient resource use there would be offset by an adverse change in the region's terms of trade when all of those countries expand their primary product exports simultaneously.

That raises the question: Would the economy of each Sub-Saharan African country be better off if its government did not participate in the next WTO round? The answer is: certainly not. On the contrary, each economy's welfare would be even worse if the government did not participate, for several reasons. First, it would forego the economic efficiency gains from reforming its own policies while still suffering the terms of trade loss from others' reforms (since any one of those countries is too small for its own policy choice to alter the terms of trade significantly). ${ }^{11}$ Second, it would forego the opportunity to seek through the negotiations greater market access for its particular exports to other countries. And third, there is the promise in this next round that any participating poor economies that lose from taking part in the multilateral liberalization could secure much more compensation than in previous rounds, in the form of technical assistance and funds for trade policy capacity building (WTO 2001b).

It is thus in the national economic interest of such countries to be pressured from abroad to commit to such reform, politically painful though that may be for their governments. The political pain tends to be less, and the prospect for a net economic

\footnotetext{
${ }^{11}$ For empirical support for this proposition, see for example Anderson and Strutt (1999) with respect to Indonesia. The point is made strongly also in the volume on the Uruguay Round edited by Martin and Winters (1996).
} 
gain greater, the more sectors the country involves in the reform. The economic gain is prospectively greater the more sectors it involves because a wider net reduces the possibility that reform is confined to a subset of sectors that are not the most distorted. (When so confined, resources might move from the reformed sector to even more inefficient uses, thereby reducing rather than improving the efficiency of national resource use - see Lloyd 1974.)

\section{Qualifications to the global modeling results}

There are three other important sources of gains from trade reform that are not captured in the above results, namely, gains from reform of trade in services, gains from increasing competition and economies of scale, and dynamic gains.

The nature of service sector policies makes estimating their effects much more difficult than is the case for goods barriers to trade in goods. Nonetheless, preliminary empirical attempts suggest restrictions on services trade and investment flows are very substantial, particularly by developing countries (Findlay and Warren 2000). Moreover, the GATS negotiations during the Uruguay Round resulted in almost no commitments to lowering those impediments (Hoekman 1996). During that Round many developing countries considered the negotiations that led to the General Agreement on Trade in Services (GATS) as something they had to put up with in order to get agriculture and textiles 'concessions'. Yet the gains to developing countries from opening up their services markets, as for developed countries, would be enormous. Those gains would come not just directly to consumers but also to producers who purchase services as intermediate inputs into their goods production. Farmers in particular would benefit from services reform because they depend heavily on such things as transport services to get their produce to domestic and overseas markets (Anderson and Hoekman 2000).

While measuring distortions to services trade and mark-ups by imperfectly competitive firms is fraught with difficulty, initial attempts are beginning to bear fruit. A study by Francois (2001) includes one set of estimates of the tariff equivalent of those distortions in a version of the GTAP model that also incorporates imperfect competition and scale economies. Specifically, that study assumes monopolistic competition exists in the non-primary sectors involving economies of scale that are internal to each firm. These modifications amplify the estimated gains from trade considerably. For example, that study finds that if applied tariff rates for both goods and services were to be cut in half, the global gains would be US\$385 billion, of 
which 51 percent would be due to services reform. The 49 percent due to halving tariffs on goods trade ( $\$ 192$ billion) in the Francois study compares with the above estimate (where no imperfect competition is assumed) of around $\$ 250$ billion from totally removing all tariffs on merchandise trade. The key point to draw from this comparison is that the gains from trade reported above should be interpreted as lowerbound estimates for at least two reasons: because they apply only to goods trade, leaving aside the important distortions prevalent in services markets; and because they are based on the assumption that there are no economies of scale and that perfect competition prevails in all sectors.

None of the studies reported above draws on a truly dynamic economic model. They measure well the effects of producers reallocating their resources and consumers adjusting their purchases when relative product prices change with trade reform, but they do not measure the impact of such reform on investment behavior. Yet we know from experience that when markets are freed up, investors divert their funds toward expanding the now-more-profitable activities and away from the now-less-profitable ones. They are also willing to invest more in aggregate, because of the reduced uncertainty associated with binding the reforms in WTO schedules. That boost to investment applies even more following the reductions in barriers to foreign investment and hence international technology transfers of the past two decades. Thus economic growth is boosted by that diversion and expansion of investment funds, over and above the boost in output from reallocating existing resource endowments.

This additional effect is omitted from most empirical modeling efforts for two reasons: partly because it takes much longer for analysts to build and to run dynamic models than comparative static ones, and partly because the extent to which investors respond to changing incentives is less well understood and hence cannot be included with as much certainty as the other behavioral characteristics that are common to both comparative static and dynamic models. Keeping that in mind, it is nonetheless instructive to note the results of a recent study that examines the range of outcomes generated as the responsiveness of productivity to openness is varied.

The World Bank (2002, Ch. 6) conducted a study very similar to the one reported above, and obtained very similar results when its version of the GTAP model was in comparative static mode (a global welfare gain from complete liberalization of merchandise trade of $\$ 355$ billion per year by 2015 , compared with the present study's estimate of $\$ 254$ billion as early as 2005 when the world economy would be somewhat smaller, and with agricultural policies still responsible for about two-thirds 
of that gain). When their same model was switched into dynamic mode, however, that global gain increased two- to three-fold over reasonable ranges of productivity responsiveness parameters. This adds further weight to the claim that the earlier welfare results should be considered as very much lower-bound estimates of the gains from trade liberalization. ${ }^{12}$

In short, developing countries as a group have much to gain economically from taking part in the next round of WTO negotiations to liberalize trade, and more so the more they are willing to embrace reform at home so as to enable their firms to take greatest advantage of the opportunities provided by the opening up of markets abroad. And this applies especially to agricultural trade reform.

\section{Effects of further trade reform on various types of developing countries}

In thinking about the effects that further trade reform could have on developing countries, it is helpful to recognize that developing countries are quite heterogeneous in their degree of food nutrition and in their production and trade specialization patterns. This is evident, for example, in the sample of 23 countries included in a recent FAO study on the impact of the Uruguay Round (Mathews 2002). Table 4 shows that the proportion of the population that is undernourished is not highly correlated with the income grouping of countries. Also clear from the table is that not all low-income countries are classified as LDCs (least-developed countries), nor is the subset of them that are net importers of food defined on a calorie basis highly correlated with the WTO's list of so-called NFIDCs (net food-importing developing countries). And the countries shown vary hugely in the value of their food imports when expressed as a percentage of either total exports or just exports of agricultural products, with again not a high correlation between those indicators and the food-deficit status of countries. Given that heterogeneity, it is helpful for present purposes to categorize developing countries as follows:

- Net exporters of foods protected by OECD countries (grains, meats, dairy products, oilseed products, sugar, fruits and vegetables);

- Those sufficiently close to self-sufficient in protected OECD products as to be likely net exporters under global free trade;

\footnotetext{
${ }^{12}$ An important caveat to all these studies is they assume the aggregate levels of employment of existing resources including labour remain unchanged during the period of adjustment to the reforms. In so far as there is some temporary unemployment and some loss of industry-specific human capital, those costs would need to be subtracted from the amortised value of the flow of benefits as estimated in the simulation studies.
} 
- Those net food importers who would remain so under free trade at home and abroad and are net exporters of:

○ Tropical agricultural products (e.g. beverages)

○ Non-agricultural primary products (e.g. petroleum)

○ Non-primary products (e.g. textiles and clothing).

With those categories in mind, we turn to some of the concerns raised in the paper's introduction.

Does it matter that global trade reform erodes tariff preferences?

Among the net exporters of foods protected by OECD countries are developing countries that receive some form of preferential access to OECD country markets. Such countries typically have put their negotiating efforts more into seeking extensions of preferential trading schemes than into cuts to remaining most-favorednation (MFN) barriers to trade in agricultural, textile or other products. While that option is currently still before them, it is worth considering whether it is wise to take it up.

There are several types of preferential access schemes that have been designed to mitigate the effects of high tariffs on exports from developing countries to advanced economies. They range from very broad ones with minor tariff concessions, such as the Generalized System of Preferences (GSP), to market-specific ones such as the European Union's provision of duty-free access for certain volumes of certain products from certain developing countries (mostly former colonies of EU member states) in Africa, the Caribbean and the Pacific (ACP - formerly the Lome Convention, now the Cotonou Agreement), to the new EU proposal for duty- and quota-free access for most exports from the least developed countries (LDCs, as classified by the United Nations). To what extent are these arrangements stepping stones or stumbling blocks towards better market access abroad for poor countries? In particular, how effective are these arrangements as compared with MFN liberalizations under the WTO in delivering benefits to poorer economies (as distinct from just being easier politically for national governments to sign)?

African, Caribbean and Pacific (ACP) developing countries that have been granted preferential access to European Union markets for some of their exports typically consider themselves privileged, believing that it better enables them to compete in those markets. Not only do they not have to pay the same import duty as other foreign suppliers, but also they receive the EU domestic price, which is higher 
than the international price to the extent of the protection afforded by the tariff and other restrictions such as quotas on non-ACP imports.

Beneficial though this might sound, five important points need to be borne in mind. First, many other equally poor but non-ACP developing countries are harmed by the ACP preferences. This was made abundantly clear in the 1990s during the infamous dispute-settlement case that was brought to the WTO concerning the EU's banana import regime. One background study showed that for every dollar of benefit that the banana policy brought to producers in ACP countries, the regime harmed nonACP developing country producers by almost exactly one dollar - and in the process harmed EU consumers by more than thirteen dollars (Borrell 1999a). It is difficult to imagine a more inefficient way of transferring welfare to poor countries, since EU citizens could have, through direct payments, been 13 times as effective in helping ACP banana producers and not hurt non-ACP banana producers at all. Such wasteful trade diversion is avoided under non-discriminatory, most-favored-nation (MFN) liberalizations that result from multilateral trade negotiations under WTO.

Second, the additional production that is encouraged in those ACP countries when they get privileged access to the high-priced EU market is not internationally competitive at current prices (otherwise it would have been produced prior to getting that preferential treatment). Indeed the industry as a whole may not have existed in the ACP country had the preference scheme not been introduced. ${ }^{13}$ In that case, its profits are likely to be lean despite the scheme, and would disappear if and when the scheme is dismantled. Efforts to learn the skills needed, and the sunk capital invested in that industry rather than in ones in which the country has a natural comparative advantage, would then earn no further rewards.

Third, the ACP preferential access scheme under the Lome Convention has not been a reciprocal agreement, that is, the developing countries were not required to open their markets to EU products. While that makes life easy for ACP politicians, it contributes nothing to the removal of the wasteful trade-restrictive policies of the ACP countries. This contrasts with market access negotiations under WTO, which are characterized by reciprocity: you receive greater access to my markets (on an MFN basis) on the condition that your trading partner receives a similar degree of improvement in access to your markets.

\footnotetext{
${ }^{13}$ Alternatively, the ACP scheme may have caused an existing industry to become less competitive. An extreme example of an industry that has ossified as a consequence of regulations introduced to share the expected benefits of EU preferences is sugar in Mauritius (Borrell 1999b).
} 
Fourth, in so far as a developing country sells only part of its exports into a protected market to which it has preferential access, it receives a lower price for the rest of its exports than would be the case under free trade because of the pricedepressing effect of that OECD protection on the free international market. It is therefore conceivable that the weighted average price for its exports is lower than what it would be under free trade, notwithstanding the benefit of preferential access for some of its exports.

Fifth and perhaps most importantly, the ACP preference scheme reduces very substantially the capacity for developing countries as a group to press for more access to EU markets. It does this in two ways: by reducing the number of such countries arguing against protection, and by creating a subset of developing countries supporting the EU's protectionist stance (in order to continue to receive the high domestic prices in the EU market). This point is crucial, and yet it is often not appreciated. Perhaps if these preferences had not been offered in the first place, developing countries would have negotiated much more vigorously in previous GATT rounds for lower tariffs on agricultural and other imports into the EU. That in turn would have placed greater pressure on Japan and others to reduce their agricultural protectionism also. The end result would have been higher international prices for agricultural products that, for developing country producers as a group, may have been more than sufficient to offset the lower prices received in the EU market for a favored subset of those producers.

A similar set of provisos can be made about the EU's recent proposal to extend preferences for UN-designated 'least developed countries' (LDCs). That initiative would provide duty- and quota-free access to the EU for exports of all merchandise except arms. It received in-principle, best-endeavors endorsement at the WTO Ministerial in Doha in November 2001, but without any specific timetable. ${ }^{14}$

Liberal though that proposal sounds, note that it does not include trade in services (of which the most important for LDCs would be movement of natural persons, that is, freedom for LDC laborers to work in the EU or other high-wage countries). ${ }^{15}$ Also, a number of safeguard provisions are included in addition to the EU's normal anti-dumping measures. Furthermore, access to three politically

\footnotetext{
${ }^{14}$ In Paragraph 42 of the Ministerial Declaration (WTO 2001b) it simply says: "We commit ourselves to the objective of duty-free, quota-free market access for products originating from LDCs."

${ }^{15}$ On the potential gains from freeing the temporary movement of unskilled labour services globally, see Winters, Walmsley, Wang and Grynberg (2003).
} 
sensitive agricultural markets, bananas, rice and sugar, would be phased in by the EU only gradually over the next eight years (and would be subject to stricter safeguards).

Several empirical studies of the proposal have already appeared. A World Bank study by Ianchovichina, Mattoo and Olarreaga (2001) compares the EU proposal, from the viewpoint of Sub-Saharan Africa (SSA), with recent initiatives of the United States and Japan. Their GTAP modeling results suggest that even the most generous interpretation of the US's Africa Growth and Opportunity Act (which they model as unrestricted access to the US for all SSA exports) would benefit SSA very little because the US economy is already very open and, in the products where it is not (e.g. textiles and clothing), SSA countries have little comparative advantage. Likewise they find the Japanese proposal of free access to Japan's market for industrial products helps SSA hardly at all, since the region exports few industrial products. By contrast, the EU proposal, especially if it were to apply to all Quad countries (the EU, the US, Canada and Japan), would have a sizeable effect on SSA trade and welfare provided agriculture is included in the deal. Just from EU access alone, SSA exports would be raised by more than US\$0.5 billion and SSA economic welfare would increase by $\$ 0.3$ billion per year (a 0.2 percent boost). This is very similar to a recent estimate by UNCTAD/Commonwealth Secretariat (2001, Ch. 3).

The estimated benefits are not surprising given that agriculture and food products account for more than half SSA exports. These items are highly protected in the EU and other Quad countries, and little is provided for them in the way of preferential access under the GSP. The results overstate the benefits of the EU proposal, however, as this World Bank study assumes all SSA countries (excluding relatively wealthy South Africa and Mauritius), not just the LDCs amongst them, would get duty- and quota-free access.

Another World Bank study, by Hoekman, Ng and Olarreaga (2002), uses a partial equilibrium approach and looks at the benefit of the EU initiative for LCDs not just in SSA but globally. It finds that trade of LDCs would increase by US $\$ 2.5$ billion per year if all Quad countries provided them duty- and quota-free access on all merchandise. ${ }^{16}$ However, almost half of that increase would come as a result of trade diversion from other developing countries. The authors suggest this is trivial because it represents less than 0.1 percent of other developing countries' exports (about $\$ 1.1$

\footnotetext{
${ }^{16}$ This and other estimates of gains from preferential market access provisions need to discounted to the extent that rules of origin, sanitary and phytosanitary barriers, anti-dumping duties and the like limit the actual trade allowed. For a detailed analysis of these types of restrictions on EU imports from Bangladesh in recent years, see UNCTAD/Commonwealth Secretariat (2001, Ch. 5).
} 
billion). ${ }^{17}$ That misses a similar point to the one made above, however. It is that if the 48 LDCs are given such preferences, they will become advocates for rather than against the continuation of MFN tariff peaks for agriculture and textiles - diminishing considerably the number of WTO members negotiating for their reduction. It may be true that reductions in agricultural and textile tariffs would help LDCs much less than they would help other developing countries, as the study by Hoekman, $\mathrm{Ng}$ and Olarreaga (2002) finds; but the gains to consumers in the Quad would be more than sufficient to allow them to increase their aid to LDCs to compensate for the loss of income from preference erosion. To put the point in a blunter but more general way, trade can be worse than direct aid if the trade is preferential and thereby distortionary.

\section{Wouldn't net food-importing developing countries lose from higher food import bills?}

Among the net food-importing developing countries (NFIDCs), some fear agricultural protection cuts by OECD countries will lead to an unaffordably higher international food import bill. Yet even those developing countries - which may be part of one of the country aggregates in Table 2 - need not lose out from farm support cuts abroad. If, for example, they are close to self-sufficient in food without price supports (as many net food-importing developing countries are), and reform abroad raises the international price of food, they may switch to become sufficiently exportoriented that their net national economic welfare rises. A second possibility is that the developing country's own policies are sufficiently biased against food production that the country is a net importer, despite having a comparative advantage in food. In that case, the international price rise can improve national economic welfare even if the price change is insufficient to turn that distorted economy into a net food exporter. That comes about because the higher price of food attracts mobile resources away from more-distorted sectors, thereby improving the efficiency of national resource allocation. Because of these two possibilities, the number of poor countries for which a rise in international food prices might cause some hardship is much smaller than the number that are currently not net exporters of agricultural products. Indeed, using a partial equilibrium model of the world's food markets, Anderson and Tyers (1993) find that all food-importing developing country regions (excluding East Asia's newly industrialized economies) would have gained in the early 1990s from OECD

\footnotetext{
${ }^{17}$ The impact outside the LDC group would be far from trivial for Mauritius, however, since the vast bulk of its exports are quota-restricted sales of clothing and sugar to the EU and US. See the discussion in UNCTAD/Commonwealth Secretariat (2001, Ch. 6).
} 
agricultural trade and subsidy reform, and none would have ended up with an increased food import bill.

What about each of the NFIDCs within those regions? Some are exporters of tropical agricultural products such as beverages, while others export energy raw materials or other mining products. They would be less concerned about a higher food import bill if they received in return better access to OECD markets for moreprocessed versions of their primary products. Tariff escalation in many instances makes access difficult through raising the effective protection to processors in OECD countries, which crowd out potential exports from developing country processors.

What about those developing countries whose comparative advantage is gradually moving from primary products to (initially unskilled) labor-intensive manufactures, as in much of Asia? While industrialization lowers their direct interest in agricultural trade reform abroad, it heightens their keenness to see barriers to exports of textiles and clothing lowered. Their interest in textile trade expansion should be shared by agricultural-exporting developing countries, for if the former group could export more manufactures, it would tend to become a larger net importer of agricultural products. Conversely, lowered industrial-country barriers to agricultural trade would reduce the need for the more land-abundant developing countries to move into manufactures in competition with the newly industrializing ones. Scope clearly exists for the two groups to band together and negotiate as a single voice calling for barriers to both farm and textile trade to be lowered, so that each group can better exploit its comparative advantage to the direct benefit of the vast majority of poor people in both. If that means lowering protected domestic food prices, some farm laborers will find jobs in the expanding light industrial sector where wages will have risen. Even those staying in agriculture need not lose, if savings from cuts in price supports were used to reduce under-investment in such areas as agricultural R\&D and rural roads, education and health.

\section{Effects of further reform on different households within developing countries}

Another important distinction is that between various types of households within each developing country. For present purposes the key household types to distinguish are net sellers of food, landless farm laborers, and non-farm low-skilled laborers (including underemployed workers). Those households mainly supplying non-farm skilled labor and/or capital typically are not poor and so are of less concern 
here. Bearing this in mind, we turn to two additional questions raised in the introduction.

Wouldn't higher international food prices increase poverty and food insecurity for poor households?

The impact of trade liberalization on income distribution and thereby on poverty at the household level is not always clear: even though the effects of trade policies on capital owners and workers have been studied by trade theorists for centuries, applying that theory to the real world turns out to be a complex empirical task (Winters 2002; McCulloch, Winters and Cirera 2001; Hoekman et al. 2001). This is because the economy-wide effects depend (a) on the shares of households' income from different productive factors such as labor and land, whose prices will have changed (depending on the size of the changes in relative producer prices, factor substitutability, factor intensities, and factor mobility between sectors), (b) on their expenditure shares on different products (whose consumer prices also will have changed and not necessarily to the same extent as producer prices not least because of marketing margins), and (c) on any changes in net transfers to them (e.g. increased handouts, decreased taxation, more remittances from urban relatives). Those complexities make it difficult to generalize a priori, or even in the face of empirical modeling studies when they report effects of reform just on production, trade, product prices and aggregate economic welfare. Even so, some observations are worth making about the effects on poverty and food security of reducing agricultural protectionism globally.

Most low-income countries have not propped up the producer price of food. In so far as an international food price rise is transmitted domestically, ${ }^{18}$ the vast majority of the poor would benefit directly. This is because they are in farm households and are net sellers of food. Even poor landless farm laborers who are net buyers of food would benefit indirectly from agricultural trade liberalization via a rise in the demand for their unskilled farm labor, assuming that raises their wage sufficient to more than offset the rise in food prices in rural areas. Since the more affluent people in cities would find it relatively easy to pay a little extra for food, the only other major vulnerable group is the under-employed urban poor. But even that group

\footnotetext{
${ }^{18}$ The elasticity of price transmission is usually less than one for importing countries, especially in the short run where governments intervene at the border in an attempt to cushion the domestic market from international price fluctuations (Tyers and Anderson 1992, Sharma 2003). And it is typically much lower in remote rural locations than in urban settings close to the nation's border.
} 
may not be worse off in so far as trade reform generates a more-than-offsetting increase in the demand for (often informal sector) services that use that group's labor relatively intensively.

What about the impact of reform on food price variability and other aspects of food security, especially as it affects the poorest households? Contrary to popular belief, trade liberalization is much more likely to reduce than raise food insecurity for the vast majority of the world's poor. Food security means always having access to the minimum supply of basic food necessary for survival. The key to that, in addition to peace and greater efficiency in the functioning of staple food markets, is strengthened purchasing power of the poor. That is, enhancing food security is mainly about alleviating poverty. The rate of food self-sufficiency is at most only a supplementary indicator, and only while there remains a perception that food insecurity rises when the level of food self-sufficiency in basic foods falls much below 100 percent.

Eliminating all agricultural policy distortions in developed countries would raise international prices for agricultural products on average, and reduce their variance by 'thickening' the market, which would stimulate production in nonprotected countries. ${ }^{19}$ According to one recent study (Diao, Somwaru and Roe 2001), that would boost the value of agricultural exports of developing countries by 24 percent and dampen their agricultural imports by 2 percent. That suggests food selfsufficiency in many low-income countries would rise. As well, since a high proportion of the poorest households in developing countries are producers and net sellers of food, they would benefit from such reform. In both respects, therefore, food security for the vast majority of households in low-income countries should be enhanced on average. Those same households would be helped even further if agricultural price-depressing policies were in place domestically and these are removed. The latter reform also boosts self-sufficiency in agricultural products and thereby boosts even further perceived food security in those economies.

The Diao, Somwaru and Roe (2001) study estimates that eliminating developing countries' own agricultural price distortions would boost their farm export value by a further 6 percent. True, the households that are net buyers of food in such economies will face higher food prices; but whether they become less food secure

\footnotetext{
${ }^{19}$ Unfortunately 'dirty' tariffication and the continuing use of specific tariffs by developed countries, the setting of high ceiling bindings by developing countries, and the introduction of tariff rate quotas greatly weakened (relative to pure ad valorem tariffication) the extent to which the Uruguay Round Agreement on Agriculture raised the mean and lowered the variance of international food prices during the past seven years.
} 
depends also on what happens to their earnings (and/or transfers). If they are landless rural poor, their earning prospects will have risen along with the growth in demand for farm labor, or for labor in local enterprises that grow as farmers spend their enhanced income on simple manufactures and services made nearby. As for urban households, the vast majority of them are more affluent than those in rural households and so can well afford to pay higher market prices for food. This suggests only a small proportion of households in low-income economies would be net food buyers at risk of becoming more food-insecure as a result of rising domestic food prices following trade liberalization. Even that group could be better off if developed countries were to reduce also their barriers to imports of textiles and clothing, since that would expand the demand for unskilled labor in the apparel industry of developing countries.

What about in developing countries where agricultural trade liberalization means lower domestic prices for agricultural products because such countries have kept domestic food prices above international levels via import restrictions? It is true that removing those distortions will reduce farm incomes in those countries (but by more for larger than smaller farms), and urban households will benefit from lower food prices. However, food self-sufficiency will fall - and it is the fall in both farm earnings and food self-sufficiency that focuses the attention of those who argue that agricultural trade liberalization is bad for poor households. Focusing on just the direct effects of agricultural trade policy reform can be misleading, however, not least because it does not take account of the fact that such reform is typically done in the context of multilateral, economy-wide liberalization. Being multilateral means that other countries' farm protection cuts raise international food prices, and so less of a price fall occurs than when a country cuts it agricultural protection unilaterally. And being economy-wide means the decline in demand for farm labor is more or less than offset by a growth in demand for labor in expanding non-farm industries.

In short, at least two points are worth stressing. ${ }^{20}$ First, reducing agricultural policy distortions in developed countries would increase the mean and decrease the variance of international prices for agricultural products, which would stimulate production in other countries. That suggests food self-sufficiency would rise in those developing countries that transmit international prices to their domestic market. Second, since a high proportion of the poorest households in low-income countries

\footnotetext{
${ }^{20}$ For a more in-depth analysis of the food security aspects of WTO farm trade reform, see DiazBonilla, Thomas and Robinson (2003).
} 
are producers and net sellers of food, they would be key beneficiaries of such reform. In both respects, therefore, food security for the vast majority of households in lowincome countries should be enhanced on average. Those same households would be helped even further by the reduction/removal of any policies that are depressing farmers returns (e.g., directly via agricultural export taxes or indirectly via import protection for non-agricultural sectors or an over-valued currency). The latter reform also boosts self-sufficiency in agricultural products and thereby boosts perceived food security even further in those economies.

What about lowering domestic food prices in protective developing countries, as with China's accession to WTO?

Those food-importing developing countries that currently protect their farmers have a different set of concerns. The case of China's accession to WTO illustrates the situation. That accession, which will be on-going until the latter part of the present decade, involves a decline in the domestic price of some farm products. Because farm households in China are among the country's poorest, that trade reform is often pointed to as an example of one that will exacerbate poverty. To explore that possibility, a set of empirical studies was commissioned recently by the World Bank. A global economy-wide numerical simulation model was used to generate the changes in product and factor prices expected from the commitments to reform that China made in its accession negotiations. These were then mapped to the earning and spending patterns of various household types and regions in China as revealed in China's rural and urban household surveys.

The conventional wisdom that China's WTO accession will impoverish its rural people, via greater import competition in its agricultural markets, need not prevail. One needs to keep in mind that, even if prices of some (land-intensive) farm products fall, those for other (labor-intensive) farm products could rise. Also, the removal of restrictions on China's exports of textiles and clothing will boost town and village enterprises, so demand for non-farm workers in rural areas may grow even if demand for farm labor in aggregate falls.

New estimates of the likely changes in agricultural prices as a result of WTO accession are drawn on to examine the factor reward implications of China's WTO accession empirically using the GTAP model. Results reported in Anderson, Ianchovichina and Huang (2004) suggest farm-nonfarm and Western-Eastern income inequality may well rise but rural-urban income inequality need not. That conclusion 
is supported by a more-detailed study of households by Chen and Ravallion (2004). They find negligible impacts on inequality and a small reduction in poverty in aggregate, but some variance across households and regions. Farm households tend to lose, especially those highly dependent on feed grain production (in Northeastern China) and in hinterland regions with weak links to the booming non-farm sectors and eastern provinces. But the losses are at most very small, amounting to less than 5 percent of household income. Facilitating the transfer of some labor from lesslucrative farm activities to now-more-lucrative non-farm work could be sufficient (with the usual remittances back to the farm household) to ensure all gain from China's WTO accession.

A companion study by Ianchovichina and Martin (2004) also examines how much difference it could make if the hukou system that restricts rural-to-urban migration were to be abolished. Their results suggest that the sign of the effects could be switched to favor the poorer farm households - albeit at the expense of the richer non-farm ones - if the remaining WTO accession-related reforms were to be accompanied by reform of the hukou system that allowed some members of those households to obtain higher-paying non-farm employment and repatriate earnings back to their farm family. And of course aggregate national economic welfare would be enhanced by that labor market reform as well. This illustrates the general point that gains from trade reform will be greater, the more liberal are domestic product and factor markets.

A summary of those modeling results can be seen in Table 5. Without labor market reform, WTO accession for China would slightly reduce rewards to unskilled farm labor and to agricultural land while raising rewards to all other factors of production. That suggests farm households earning less than 60 percent of their income from unskilled nonfarm work could be harmed (albeit only slightly) from WTO accession. If complete abolition of restrictions to off-farm migration accompanied WTO accession reforms, however, the final column of Table 5 suggests all types of farm households could be better off as more family members are attracted to higher-paying off-farm work.

In so far as China's WTO accession puts upward pressure on international farm product prices, that would have the same pro-poor consequences in other developing countries as the multilateral farm trade reform discussed above. However, the extent of that price rise and the associated increase in China's imports of farm products is going to be minor, and certainly will not, as implied by the title of Lester 
Brown's 1995 book, 'starve the world' (see the empirical results in Anderson et al. 1997).

\section{What are the risks of re-instrumentation of agricultural protection?}

If increasing market access in OECD countries through reducing farm production and export subsidies and agricultural protection is able to contribute to poverty alleviation in developing countries, then to what extent would that objective be compromised by efforts to substitute new forms of assistance to farmers as traditional protective instruments are phased out? The imposition of tariff rate quotas accompanied by very high out-of-quota tariffs, and the administration of quotas so as to ensure less than full usage of them, were two ways in which agricultural protection changes following the Uruguay Round were minimized - to the point that many developing countries struggled to identify any significant growth in agricultural export earnings resulting from the UR Agreement on Agriculture (Mathews 2002). ${ }^{21}$

There are at least two ways in which cuts in assistance to developed country farmers may be minimized following the Doha Round too. One is via an expansion of exempt support measures to satisfy so-called non-trade concerns related to the alleged 'multifunctionality' of agriculture - even though those concerns can readily be met much more directly and hence in less trade-distorting ways than is being proposed (Anderson 2000; Paarlberg, Bredahl and Lee 2002). While the multifunctionality concept originated in the richest, most-protective economies, it is now being embraced by farmer groups in numerous developing countries as well. More than 20 such countries' farm groups plus the EU met in Geneva 23-25 October 2002 and signed a declaration calling on WTO members to acknowledge that "agriculture cannot be treated in the same way as industrial sectors" because farming "fulfils a multitude of functions ..." Since then, however, some developing countries have been at pains to stress that their concerns are very different from those emphasized by rich countries.

The other likely form of re-instrumentation is via the adoption of stricter standards that then act as technical barriers to trade. Quarantine measures are an obvious case in point. They often add relatively large cost burdens to exporters from poorer countries because those countries do not have the same capability as developed

\footnotetext{
21 There may have been some as-yet-unmeasured benefits to the extent developing countries were granted the rents from TRQs imposed by developed countries (which would make their effects similar to the VERs imposed on textile exports from developing countries).
} 
countries to meet high standards, nor the same imperative to impose them to satisfy domestic consumers (Wilson 2002). ${ }^{22}$ Numerous developing countries have cited examples of SPS measures of OECD countries that are already significantly hindering their exports (Matthews 2002). Another is the increasing use of geographical indications and traditional expressions aimed at differentiating rich-country products, which effectively reduces the demand for more-standard substitute products from other countries. ${ }^{23}$ A third and less-obvious possibility is the restriction of imports of food products containing genetically modified organisms (GMOs). The direct, shortterm effects of a ban on GMOs could help exports from developing countries that choose not to adopt GMOs, even though it harms those who have already adopted GMOs (Nielsen and Anderson 2001; Anderson and Yao 2003a; Anderson and Jackson 2003). But the indirect, longer-term, and potentially much larger effects are adverse for the world's poor, namely, the disincentive effect of such restrictions on investment in agricultural biotechnologies that could lower food prices and/or raise the nutritional attributes of foods available in developing countries (not to mention the potential damage a GMO trade dispute could inflict on the global trading system - see Isaac and Kerr 2003).

\section{Moving forward}

\section{How can the prospects for and benefits from reform be maximized?}

Consumers in developed countries are more concerned with food safety and the environment than with the price-raising effect of agricultural protection. They are therefore not a force for reform except perhaps for switching support to payments tied to better environmental or food safety outcomes. So the political force for agricultural (and textiles and clothing) reform in developed countries has to come from those countries' exporters of other industrial goods and of services. That requires developing countries providing increased access to those producers' exports as a quid pro quo. Such reform would provide additional benefits to the farm sector of poor countries, both directly through lower-cost inputs and indirectly through the currency devaluation that would accompany it. While the farm sector is typically a weak

\footnotetext{
${ }^{22}$ Quarantine barriers are also more costly than equivalently trade-restrictive import tariffs or quotas for the imposing countries, since the latter generate tariff revenue or quota rents whereas for the former that revenue is absorbed in costs of compliance.

${ }^{23} \mathrm{See}$, for example, the concerns raised by Cairns Group members in WTO (2001c). An analysis of the prospects for producers in developing countries also harnessing geographical indications as a marketing tool is provided in Maskus (2003).
} 
lobbying force in poor countries, membership in or association with a coalition such as the Cairns Group could enhance its lobbying skills. ${ }^{24}$ So too could support from the more-enlightened non-government development agencies that realize how damaging OECD farm policies are to sustainable development in poorer countries (see, e.g., Oxfam 2002).

As mentioned above, textile and clothing exporters have an indirect interest in seeing agricultural protection reductions in their own country as well as in the OECD, so that potential food-exporting countries can access those markets instead of competing with them by turning to manufacturing. An alliance between those two types of developing countries would allow them to jointly push for greater agricultural and textile market access in rich countries.

People in developing countries also need to recognize that while so-called special and differential treatment (such as slower reform for developing countries, as in the Harbinson proposal for the Doha round) may be what their governments prefer for political reasons, it is not in the economic interests of developing country citizens. Faster and larger reforms bestow greater national economic gains from trade liberalization.

To maximize the gains from trade reform, however, developing countries need to have well-functioning domestic economies. If factor markets are inflexible, or public infrastructures are in poor shape, only a fraction (and possibly a small fraction) of the potential gains from trade reform will be realized.

\section{How best to deal with residual concerns about food security?}

If a society would feel too food-insecure under laissez faire, then what needs to be determined is a sense of (a) its willingness to pay for more security by various means, and (b) the costs of those insurance measures. One such measure involves encouraging the holding of food stocks above those that would be commercially viable -- a public good that is explicitly allowed for in Annex 2 of the WTO's Agreement on Agriculture. The optimal level of encouragement is that which boosts stocks so that the marginal social benefit in terms of food security equals the marginal

\footnotetext{
${ }^{24}$ Within agriculture, developing countries' interests in Doha agenda items align closely with those of the Cairns Group of non-subsidizing agricultural-exporting countries (Bjornskov and Lind 2002). See Cairns Group (2002) for its proposal on market access in the Doha Round. To many people's surprise a group of 20+ developing countries led by Brazil, China and India did coalesce at the Trade Ministerial meeting of WTO members in Cancun, Mexico in September 2003 and effectively brought the meeting to a close by demanding more agricultural reform in OECD countries than the EU and US were willing to offer at the time.
} 
social cost of that intervention. Costs are non-trivial, however. Storage and interest costs and the costs of spoilage and quality deterioration can amount to more than 20 percent a year. The cost part of the calculation also would need to include the risk of government failure if stocks were to be managed by an inefficient (or corrupt) public agency.

If greater domestic production capability was considered by society to be one of the desirable means of boosting food security (because of a perception that food import dependence is too unreliable), there are far less costly ways of achieving that than via farm product price supports and import protection. For example, boosting production alone, rather than also taxing consumption as with an import barrier, would be a lower-cost and less-trade-distorting means of achieving that end. Even more effective could be improvements in land tenure and more investment in the stocks of primary factors used in food production: agricultural research, ${ }^{25}$ rural human capital, and rural infrastructure (Otsuka 2002). Such efforts would provide an especially high payoff in situations where, as in so many countries, there has been gross under-investment in these activities in the past. Simultaneously, production could be boosted in many low-income countries simply by better clarifying and enforcing land rights, since they are a key source of collateral for securing loans for productive investments by farm households.

Where targeted programs to boost the earning capacity of the poverty-stricken (e.g. via basic education/training) are still not enough to boost food security in the short term, targeted consumer subsidies to provide that core group with food staples are much less costly than general subsidies to all food consumers via price-depressing agricultural policies. Food aid that is targeted to just that group could be readily provided by the international community without depressing very much the prices received by farmers in recipient countries. ${ }^{26}$ And greater technical and economic cooperation in the areas of agricultural research, rural education and health, and rural infrastructure may be important co-requisites of trade policy reform if developing countries are to be convinced that they would gain unequivocally from the Doha round.

\footnotetext{
${ }^{25}$ For recent reviews of the substantial contribution that a further boost to agricultural research could do for poverty alleviation in low-income countries, see Hazell and Haddad (2001) and Runge et al. (2003).

${ }^{26}$ If such subsidies are only paid in the towns and cities, however, this increases the risk of excessive, socially costly migration out of agriculture as analysed by Harris and Todaro (1970).
} 


\section{References}

Anderson, K. (2000), 'Agriculture's Multifunctionality and the WTO', Australian Journal of Agricultural and Resource Economics 44(3): 475-94, September.

Anderson, K., B. Dimaranan, T. Hertel and W. Martin (1997), 'Economic Growth and Policy Reforms in the APEC Region: Trade and Welfare Implications by 2005', Asia-Pacific Economic Review 3(1): 1-18, April.

Anderson, K., B. Dimaranan, J. Francois, T. Hertel, B. Hoekman and W. Martin (2001), 'The Cost of Rich (and Poor) Country Protection to Developing Countries', Journal of African Economies 10(3): 227-57.

Anderson, K. and B. Hoekman (2000), 'Developing Country Agriculture and the New Trade Agenda', Economic Development and Cultural Change 49(1): 171-80, October.

Anderson, K., E. Ianchovichina and J. Huang (2004), 'Impacts of WTO Accession on Chinese Agriculture and Rural Poverty', Ch. 7 in China and the WTO: Accession, Policy Reform, and Poverty Reduction Strategies, edited by D. Bhattasali, S. Li and W. Martin, London and New York: Oxford University Press.

Anderson, K. and L.A. Jackson (2003), 'Standards, Trade and Protection: The Case of GMOs', paper presented at a seminar at the World Bank, Washington DC, 2 October.

Anderson, K. and A. Strutt (1999), 'Impact of East Asia's Growth Interruption and Policy Responses: The Case of Indonesia', Asian Economic Journal 13(2): 205-18, June.

Anderson, K. and R. Tyers (1993), 'More on Welfare Gains to Developing Countries from Liberalising World Food Trade', Journal of Agricultural Economics 44(2): 189-204, May.

Anderson, K. and S. Yao (2003a), "China, GMOs and World Trade in Agricultural and Textile Products", Pacific Economic Review 8(2): 157-69, June.

Anderson, K. and S. Yao (2003b), 'How Can South Asia and Sub-Saharan Africa Gain From the Next WTO Round?' Journal of Economic Integration 18(3): 466-81, September.

Beghin, J.C., D. Roland-Holst and D. van der Mensbrugghe (2003), ' How Will Agricultural Trade Reforms in High-income Countries Affect the Trading Relationships of Developing Countries?' pp. 39-58 in OECD (2003).

Berg, A. and A.O. Krueger (2002), 'Trade, Growth and Poverty', paper presented at the Annual World Bank Conference on Development Economics, Washington, D.C.

Bjornskov, C. and K.M. Lind (2002), 'Where Do Developing Countries Go After Doha? An Analysis of WTO Positions and Potential Alliances', Journal of World Trade 36(3): 543-62.

Borrell, B. (1999a), 'Bananas: Straightening Out Bent Ideas on Trade as Aid', Paper presented at the World Bank/WTO Conference on Agriculture and the New Trade Agenda from a Development Perspective, Geneva, 1-2 October.

Borrell, B. (1999b), 'Sugar: The Taste Test of Trade Liberalization', Paper presented at the World Bank/WTO Conference on Agriculture and the New Trade Agenda from a Development Perspective, Geneva, 1-2 October.

Bouguignon. F. and C. Morrisson (2002), 'Inequality Among World Citizens: 18201992', American Economic Review 92(4): 727-44, September.

Brown, L.R. (1995), Who Will Feed China? Wake-up Call for a Small Planet, Washington, D.C.: Worldwatch Institute. 
Cairns Group (2002), 'Negotiating Proposal on Market Access', submission to the Committee on Agriculture Special Session, JOB(02)/1126, WTO, Geneva, September.

Chen, S. and M. Ravallion (2004), 'Household Welfare Impacts of China's Accession to the WTO', in China and the WTO: Accession, Policy Reform, and Poverty Reduction Strategies, edited by D. Bhattasali, S. Li and W. Martin, London and New York: Oxford University Press.

Collier, P. and D. Dollar (2002), Globalization, Growth, and Poverty, New York: Oxford University Press for the World Bank.

Diao, X, A. Somwaru and T. Roe (2001), 'A Global Analysis of Agricultural Reform in WTO Member Countries', Background paper for a USDA project on Agricultural Policy Reform in the WTO: The Road Ahead, ERS-E01-001, Washington, D.C.: US Department of Agriculture.

Diaz-Bonilla, E., M. Thomas and S. Robinson (2003), 'Trade, Food Security and WTO Negotiations: Some Reflections on Boxes and their Content', pp. 59104 in OECD (2003).

Dollar, D. and A. Kraay (2002), 'Growth is Good for the Poor', Journal of Economic Growth 7(3): 195-225, September.

Findlay, C.C. and A. Warren (eds.) (2000), Impediments to Trade in Services: Measurement and Policy Implications, London: Routledge.

Francois, J. (2001), The Next WTO Round: North-South Stakes in New Market Access Negotiations, Adelaide: Centre for International Economic Studies and Rotterdam: Tinbergen Institute.

Gilbert, C.L. and P. Varangis (2003), 'Globalization and International Commodity Trade With Specific reference to the West African Cocoa Producers', NBER Working Paper 9668, Cambridge MA, April.

Harris, J.R. and M.P. Todaro (12970), 'Migration, Unemployment and Development: A Two-Sector Analysis', American Economic Review 60(1): 126-42, March.

Hazell, P. and L. Haddad (2001), 'Agricultural Research and Poverty Reduction', IFPRI Discussion Paper 34, Washington, D.C.: International Food Policy Research Institute, August.

Hertel, T.W. (ed.) 1997. Global Trade Analysis: Modeling and Applications, Cambridge and New York: Cambridge University Press.

Hoekman, B. (1996), 'Assessing the General Agreement on Trade in Services', Ch. 4 in The Uruguay Round and the Developing Countries, edited by W. Martin and L.A. Winters, Cambridge and New York: Cambridge University Press.

Hoekman, B., C. Michalopoulos, M. Schiff and D. Tarr (2001), 'Trade Policy Reform and Poverty Alleviation', World Bank Trade Working Paper \# 2773, Washington, D.C., December.

Hoekman, B., F. Ng and M. Olarreaga (2002), 'Eliminating Excess Tariffs on Exports of Least Developed Countries', World Bank Economic Review 16: 1-21, January.

Ianchovichina, E. and W. Martin (2004), "Economic Impacts of China's Accession to the WTO", in in China and the WTO: Accession, Policy Reform, and Poverty Reduction Strategies, edited by D. Bhattasali, S. Li and W. Martin, London and New York: Oxford University Press.

Ianchovichina, E., A. Mattoo and M. Olarreaga (2001), 'Unrestricted Market Access for Sub-Saharan Africa: How Much is it Worth and Who Pays? CEPR Discussion Paper No. 2820, London: Centre for Economic Policy Research, June. 
Isaac, G.E. and W.A. Kerr (2003), "Genetically Modified Organisms and Trade Rules: Identifying Important Challenges for the WTO”, The World Economy 26 (1): 29-43.

Lloyd, P.J. (1974), 'A More General Theory of Price Distortions in Open Economies', Journal of International Economics 4: 365-86.

Lloyd, P.J. (2000), 'Generalizing the Stolper-Samuelson Theorem: A Tale of Two Matrices', Review of International Economics 8(4): 597-613.

Martin, W. and D. Mitra (2001), 'Productivity Growth in Agriculture and Manufacturing', Economic Development and Cultural Change 49(2): 403-23, January.

Martin, W. and L.A. Winters (eds.) (1996), The Uruguay Round and the Developing Countries, Cambridge and New York: Cambridge University Press.

Maskus, K. (2003), 'Observations on the Development Potential of Geographical Indications', background paper prepared for the $2^{\text {nd }}$ meeting of the Task Force on Trade and Finance of the UN Millennium Development Goals Project, Yale University, New Haven, 1-3 April.

Matthews, A. (2002), 'Developing Country Experience With the Implementation of the Uruguay Round Agreement on Agriculture: Synthesis of the Findings of 23 Country Case Studies', FAO Geneva Symposium on Implementing the WTO's URAA, 2 October.

McCulloch, N., L.A. Winters and X. Cirera (2001), Trade Liberalization and Poverty: A Handbook, London: Centre for Economic Policy Research.

Nielsen, C. and K. Anderson (2001), 'Global Market Effects of European Responses to Genetically Modified Organisms', Weltwertschaftliches Archiv 137(2): 32046, June.

OECD (2003), Agricultural Trade and Poverty: Making Policy Analysis Count, Paris: OECD.

Otsuka, K. (2002), 'Poverty Reduction Issues: Village Economy Perspective', Asian Development Review 19(1): 98-116.

Oxfam (2002), 'Boxing Match in Agricultural Trade: Will WTO Negotiations Knock Out the World's Poorest Farmers?', Briefing Paper 32, Brussels: Oxfam International.

Paarlberg, P.L., M. Bredahl and J.G. Lee (2002), 'Multifunctionality and Agricultural Trade Negotiations', Review of Agricultural Economics 24(2): 322-35, Fall.

Ruffin, R.J. and R.W. Jones (1977), 'Protection and Real Wages: The Neoclassical Ambiguity', Journal of Economic Theory 14: 337-48.

Ruffin, R.J. and R.W. Jones (2004), 'Real Wages and Trade: Insights from Extreme Examples', in International Trade and Development: Essays in Honour of Peter Lloyd, edited by S. Jayasuriya and P.J. Lloyd, London: Edward Elgar (forthcoming).

Runge, C.F., B. Senauer, P.G. Pardey and M.W. Rosegrant (2003), Ending Hunger in Our Lifetime: Food Security and Globalization, Baltimore: Johns Hopkins University Press.

Sala-i-Martin, X. (2002), 'The World Distribution of Income (Estimated from Individual Country Distributions)', NBER Working Paper 8933, Cambridge MA, May.

Sharma, R. (2003), 'The Transmission of World Price Signals: The Concept, Issues, and Some Evidence from Asian Cereal Markets', pp. 141-60 in OECD (2003).

Tyers, R. and K. Anderson (1992), Disarray in World Food Markets: A Quantitative Assessment, Cambridge and New York: Cambridge University Press. 
UNCTAD/Commonwealth Secretariat (2001), Duty and Quota Free Market Access for LDCs: An Analysis of Quad Initiatives, Geneva: UNCTAD and London: Commonwealth Secretariat.

Wilson, J.S. (2002), 'Standards, Trade and Development: What is Known and What do we Need to Know?' Paper presented at the Roundtable on Informing the Doha Process: New Research for Developing Countries, Cairo, 20-21 May.

Winters, L.A. (2002), 'Trade Liberalisation and Poverty: What Are the Links?' The World Economy 25(9): 1339-68, September.

Winters, L.A., N. McCulloch and A., McKay (2004), 'Trade Liberalization and Poverty: The Empirical Evidence', Journal of Economic Literature 62 (forthcoming).

Winters, L.A., T. Walmsley, Z.K. Wang and R. Grynberg (2003), 'Liberalizing Temporary Movement of Natural Persons: An Agenda for the Development Round', The World Economy 26(8): 1137-61, August.

World Bank (2001), Global Economic Prospects and the Developing Countries 2002: Making Trade Work for the Poor, Washington D.C.: The World Bank.

World Bank (2003), Global Economic Prospects 2004: Realizing the Development Promise of the Doha Agenda, Washington D.C.: The World Bank, September.

WTO (2001b), Doha WTO Ministerial 2001: Ministerial Declaration, WT/MIN(01)/DEC/1, Geneva: World Trade Organization, 14 November.

WTO (2001c), Extension of the Protection of Geographical Indications for Wines and Spirits to GIs for All Products: Potential Costs and Implications, IP/C/W/289, Geneva: World Trade Organization, 29 June. 
Table 1: Sectoral and regional contributions to economic welfare gains ${ }^{\mathrm{a}}$ from completely removing trade barriers globally, post-Uruguay Round, 2005

(a) in 1995 US\$ billions

\begin{tabular}{|c|c|c|c|c|c|}
\hline $\begin{array}{cc}\text { Liberalizing } \\
\text { Region }^{\mathbf{b}}: & \begin{array}{r}\text { Benefiting } \\
\text { region }\end{array} \\
\end{array}$ & $\begin{array}{r}\text { Agriculture } \\
\text { and Food }\end{array}$ & $\begin{array}{r}\text { Other } \\
\text { Primary }\end{array}$ & $\begin{array}{r}\text { Textiles \& } \\
\text { Clothing }\end{array}$ & $\begin{array}{r}\text { Other } \\
\text { Manufactures }\end{array}$ & Total \\
\hline \multicolumn{6}{|l|}{ High Income } \\
\hline High Income & 110.5 & -0.0 & -5.7 & -8.1 & 96.6 \\
\hline Low Income & 11.6 & 0.1 & 9.0 & 22.3 & 43.1 \\
\hline Total & 122.1 & 0.0 & 3.3 & 14.2 & 139.7 \\
\hline \multicolumn{6}{|l|}{ Low Income } \\
\hline High Income & 11.2 & 0.2 & 10.5 & 27.7 & 49.6 \\
\hline Low Income & 31.4 & 2.5 & 3.6 & 27.6 & 65.1 \\
\hline Total & 42.6 & 2.7 & 14.1 & 55.3 & 114.7 \\
\hline \multicolumn{6}{|l|}{ All Countries } \\
\hline High Income & 121.7 & 0.1 & 4.8 & 19.6 & 146.2 \\
\hline Low Income & 43.0 & 2.7 & 12.6 & 49.9 & 108.1 \\
\hline Total & 164.7 & 2.8 & 17.4 & 69.5 & 254.3 \\
\hline
\end{tabular}

(b) in percent of total global gains

$\begin{array}{crrrrr}\begin{array}{c}\text { Liberalizing } \\ \text { Region: } \begin{array}{r}\text { Agriculture } \\ \text { Befiting } \\ \text { region }\end{array}\end{array} & \begin{array}{r}\text { Other Textiles \& } \\ \text { and Food }\end{array} & \begin{array}{r}\text { Other } \\ \text { Primary }\end{array} & \text { Total } \\ \text { High Income } & & & & & \\ \text { High Income } & 43.4 & 0.0 & -2.3 & -3.2 & 38.0 \\ \begin{array}{l}\text { Low Income } \\ \text { Total }\end{array} & 4.6 & 0.1 & 3.5 & 8.8 & 16.9 \\ \begin{array}{c}\text { Low Income } \\ \text { High Income }\end{array} & \mathbf{4 8 . 0} & \mathbf{0 . 0} & \mathbf{1 . 3} & \mathbf{5 . 6} & \mathbf{5 4 . 9} \\ \text { Low Income } & 4.4 & 0.1 & 4.1 & 10.9 & 19.5 \\ \quad \begin{array}{l}\text { Total } \\ \text { All Countries }\end{array} & 12.3 & 1.0 & 1.4 & 10.9 & 25.6 \\ \text { High Income } & \mathbf{1 6 . 7} & \mathbf{1 . 1} & \mathbf{5 . 5} & \mathbf{2 1 . 7} & \mathbf{4 5 . 1} \\ \text { Low Income } & 47.9 & 0.1 & 1.9 & 7.7 & 57.5 \\ \text { Total } & 16.9 & 1.0 & 4.9 & 19.6 & 42.5 \\ \quad & \mathbf{6 4 . 8} & \mathbf{1 . 1} & \mathbf{6 . 8} & \mathbf{2 7 . 3} & \mathbf{1 0 0 . 0}\end{array}$

${ }^{\text {a }}$ No account is taken in these calculations of the welfare effects of environmental changes associated with trade liberalization, which could be positive or negative depending in part on how environmental policies are adjusted following trade reforms.

${ }^{\mathrm{b}}$ High and low income here are short-hand for developed and developing countries.

Source: Anderson et al. (2001). 
Table 2: Disaggregation of sectoral and regional contributions to economic welfare gains ${ }^{\text {a }}$ from completely removing trade barriers globally, post-Uruguay Round, 2005

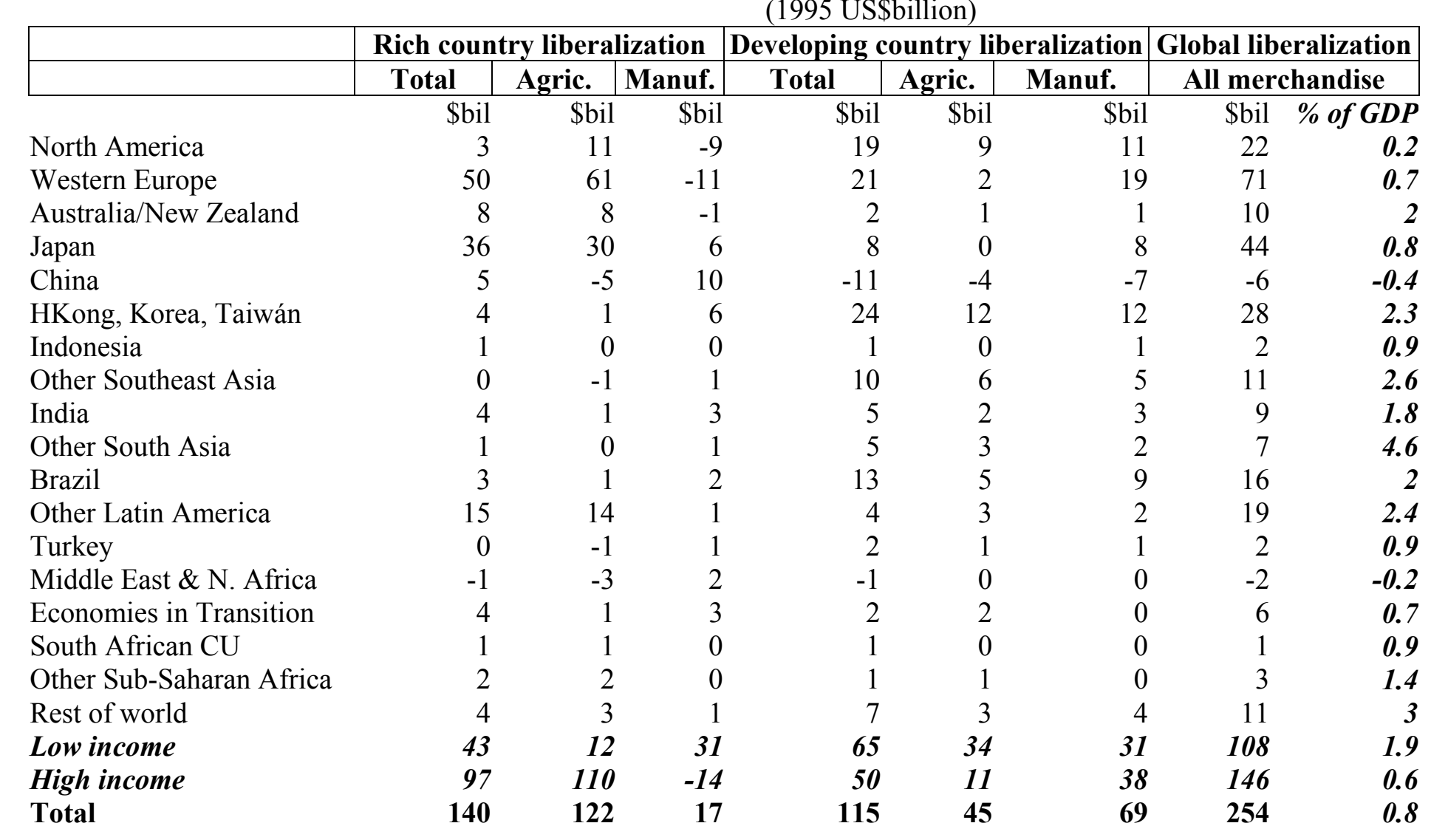

Source: Anderson et al. (2001). 
Table 3: Percentage difference in sectoral output when all merchandise trade distortions remaining post-Uruguay Round are removed, 2005

(a) Reform in all regions except Sub-Saharan Africa and South Asia

\begin{tabular}{rrrr} 
South & Other Sub- & \multicolumn{2}{r}{ Other South } \\
Africa & Sahara & India & Asia \\
& Africa & &
\end{tabular}

$\begin{array}{lrrrr}\text { Rice } & 6 & 1 & 12 & 9 \\ \text { Wheat } & 18 & 2 & 6 & 6 \\ \text { OtherCerealGrain } & 114 & 85 & 1 & 1 \\ \text { VegFruitNuts } & 1 & 0 & 1 & 1 \\ \text { OilSeeds } & 2 & 3 & -1 & 2 \\ \text { OthCrops } & 43 & -8 & -2 & 1 \\ \text { PlantFibre } & -12 & 11 & -2 & 0 \\ \text { Livestocks } & 28 & 15 & 0 & 1 \\ \text { OthFoodProd } & 28 & 2 & -2 & 29 \\ \text { MeatDairyPrd } & 38 & 14 & 1 & 3 \\ \text { ForestryFish } & 2 & 0 & 0 & 1 \\ \text { EnergMineral } & -2 & 0 & 1 & 2 \\ \text { VegOilsFats } & 0 & 0 & -4 & -5 \\ \text { TextilesClothing } & -8 & -2 & -10 & -16 \\ \text { OtherManuf } & -7 & 0 & 3 & 11 \\ \text { Services } & 0 & 0 & 0 & 0\end{array}$

(b) Reform in all regions including Sub-Saharan Africa and South Asia

$\begin{array}{rrrr}\text { South } & \text { Other Sub- } & & \text { Other South } \\ \text { Africa } & \text { Sahara } & \text { India } & \text { Asia } \\ & \text { Africa } & & \end{array}$

$\begin{array}{lrrrr}\text { Rice } & 4 & -1 & 19 & 18 \\ \text { Wheat } & -3 & -6 & 15 & 7 \\ \text { OtherCerealGrain } & 171 & 90 & 1 & 2 \\ \text { VegFruitNuts } & 1 & 9 & 0 & -3 \\ \text { OilSeeds } & -5 & -1 & 0 & 7 \\ \text { OthCrops } & 61 & 9 & -2 & -4 \\ \text { PlantFibre } & -10 & -1 & -2 & -1 \\ \text { Livestocks } & -6 & 54 & 0 & 6 \\ \text { OthFoodProd } & 22 & 3 & 1 & 38 \\ \text { MeatDairyPrd } & -6 & 0 & 2 & 8 \\ \text { ForestryFish } & 7 & 4 & 0 & 3 \\ \text { EnergMineral } & 29 & 7 & 6 & 3 \\ \text { VegOilsFats } & 0 & 2 & -15 & -17 \\ \text { TextilesClothing } & 1 & -13 & 5 & 29 \\ \text { OtherManuf } & -8 & -5 & 19 & 60 \\ \text { Services } & 1 & 0 & 2 & 4\end{array}$

Source: Anderson and Yao (2003b). 
Table 4: Income category and food trade status of a sample of developing countries.

\begin{tabular}{|c|c|c|c|c|c|c|c|}
\hline & $\begin{array}{r}\% \text { of } \\
\text { population } \\
\text { under- } \\
\text { nourished, } \\
1998-00\end{array}$ & & $\begin{array}{l}\text { ome/fo } \\
\text { tatus g }\end{array}$ & $\begin{array}{l}\text { od trade } \\
\text { roupings }\end{array}$ & & $\begin{array}{r}\text { Food } \\
\text { imports } \\
\text { as \% of } \\
\text { total } \\
\text { exports, } \\
1995-99\end{array}$ & $\begin{array}{r}\text { Food } \\
\text { imports } \\
\text { as \% of } \\
\text { agric } \\
\text { exports, } \\
1995-00\end{array}$ \\
\hline Bangladesh & 35 & LI & LDC & & LIFDC & 21 & 829 \\
\hline Botswana & 25 & UMI & & NFIDC & & 14 & 256 \\
\hline Brazil & 10 & UMI & & & & 7 & 30 \\
\hline Costa Rica & 5 & UMI & & & & 6 & 19 \\
\hline Côte d'Ivoire & 15 & LI & & NFIDC & LIFDC & 9 & 17 \\
\hline Egypt & 4 & LMI & & NFIDC & LIFDC & 20 & 542 \\
\hline Fiji & na & LMI & & & & 9 & 52 \\
\hline Guyana & na & LMI & & & & 7 & 23 \\
\hline Honduras & 21 & LMI & & NFIDC & LIFDC & 13 & 48 \\
\hline India & 24 & LI & & & LIFDC & 5 & 42 \\
\hline Indonesia & 6 & LI & & & LIFDC & 6 & 56 \\
\hline Jamaica & 9 & LMI & & NFIDC & & 12 & 111 \\
\hline Kenya & 44 & LI & & NFIDC & LIFDC & 13 & 32 \\
\hline Malawi & 33 & LI & LDC & & LIFDC & 13 & 16 \\
\hline Morocco & 7 & LMI & & NFIDC & LIFDC & 12 & 146 \\
\hline Pakistan & 19 & LI & & NFIDC & LIFDC & 15 & 134 \\
\hline Peru & 11 & LMI & & NFIDC & & 14 & 152 \\
\hline Philippines & 23 & LMI & & & LIFDC & 6 & 123 \\
\hline Senegal & 25 & LI & LDC & & LIFDC & 26 & 357 \\
\hline Sri Lanka & 23 & LMI & & NFIDC & LIFDC & 12 & 68 \\
\hline Thailand & 18 & LMI & & & & 2 & 14 \\
\hline Uganda & 21 & LI & LDC & & LIFDC & 20 & 41 \\
\hline Zimbabwe & 38 & LI & & & & 5 & 13 \\
\hline
\end{tabular}

Note: LI, LMI and UMI refer to the World Bank classifications of low-income, lower middle-income and upper middle-income countries; LDCs are least-developed countries, as recognized by the UN; LIFDCs are low-income food-deficit countries, defined by FAO as those countries with a GNP per capita less than $\$ 1,445$ in 2000 and which are net importers of food defined on a calorie basis; NFIDCs are net foodimporting developing countries, as defined by the WTO Committee on Agriculture.

Source: Compiled from data in Mathews (2002) and the FAO's State of Food Insecurity 2002, Rome. 
Table 5: Changes in China's real factor prices and national economic welfare due to its WTO accession, 2001 to 2007

(percent and, for national welfare, 1997 US\$ billions)

Factor rewards:

Farm unskilled wages

$-0.7$

16.8

Rental price of land

$-5.5$

$-9.7$

Nonfarm unskilled wages

1.2

$-3.8$

Skilled labor wages

0.8

$-1.7$

Rental price of capital

1.3

$-1.4$

\section{Farm household income ${ }^{\mathrm{a}}$ :}

Farm household type-A

Farm household type-B

Farm household type-C
$-1.6$

$-0.8$

0.1
6.8

3.6

0.4

${ }^{\text {a }}$ Farm income from agriculture is made up of 57 percent from unskilled farm labor, 26 percent from agricultural land and 17 percent from farm capital, according to the GTAP database. In 1999 on average 51 percent of rural household income in China was earned outside agriculture, mostly from unskilled labor. Therefore, to illustrate the importance of those off-farm earnings for farm families, three types of farm households are shown in this table: it is assumed nonfarm unskilled labor contributes 0 percent of total farm household income for type A, 30 percent for type B, and 60 percent for type $\mathrm{C}$.

Source: Anderson, Ianchovichina and Huang (2004) and Ianchovichina and Martin (2004). 